\title{
Biochemical markers in crop and forest species: a systematic review
}

\author{
Marcadores bioquímicos em espécies agrícolas e florestais: uma revisão sistemática \\ Marcadores bioquímicos en especies agrícolas y forestales: una revisión sistemática
}

Received: 11/30/2021 | Reviewed: 12/08/2021 | Accept: 12/18/2021| Published: 12/20/2021

Sara Lorena de Pádua Souza

ORCID: https://orcid.org/0000-0003-0682-3254

Federal University of Sergipe, Brazil

E-mail: sarapadua1999@hotmail.com

Valdinete Vieira Nunes

ORCID: https://orcid.org/0000-0002-0272-0971

Federal University of Sergipe, Brazil

E-mail: nunes.vval@gmail.com

Izabel de Jesus Candido

ORCID: https://orcid.org/0000-0002-6219-4889

Federal University of Sergipe, Brazil

E-mail: isabeldejesus6@gmail.com

Valéria Mota de Brito

ORCID: https://orcid.org/0000-0002-3742-8380

Federal University of Sergipe, Brazil

E-mail: v.motabrito@gmail.com

Lucas Alexandre dos Santos Rocha

ORCID: https://orcid.org/0000-0003-2329-9722

Federal University of Sergipe, Brazil

E-mail: Lucas1404_2411@outlook.com

Renata Silva-Mann

ORCID: https://orcid.org/0000-0001-5993-3161

Federal University of Sergipe, Brazil

E-mail: renatamann@academico.ufs.br

\begin{abstract}
Proteins and enzymes are informative biochemical markers frequently used in plant studies. The objective of this work was to present the studies with enzymes and proteins used as biochemical markers in crops and forest speciesthe articles prospected in the Scopus and Web of Science scientific databases in December 2020. The keywords were a combination of "agricultural" or "forest" with the Boolean operator and the enzymes' name: alcohol dehydrogenase/ADH, malate dehydrogenase/MDH, alpha-amylase/AMS, peroxiredoxin/PERX, and LEA proteins. Eighty-two articles addressed enzymes in agricultural or forest species were included in the analysis. The articles were published from 1976 to 2020, with an average annual publication of 12.2. Three hundred thirty-seven authors developed the annual percentage growth rate of $2.52 \%$ and articles. The most studied crops are Oryza sativa L., Glycine max L., Zea mays L., Hordeum vulgare L., specimens of the genera Triticum and Brassica. The forest species were Pinus, Picea, Nothofagus, Quercus, and Sorbus, and Fagus sylvatica L. The main tissues used for extraction are leaves, seeds, buds, and roots. The studies mainly deal with enzymes or proteins as markers associated with abiotic stresses and the structure or genetic diversity.
\end{abstract}

Keywords: ADH; Alpha-amylase; MDH; LEA Proteins; Peroxiredoxins.

\section{Resumo}

Proteínas e enzimas são marcadores bioquímicos informativos frequentemente usados em estudos de plantas. O objetivo deste trabalho foi apresentar estudos com enzimas e proteínas utilizadas como marcadores bioquímicos em culturas e espécies florestais. Os artigos foram prospectados nas bases de dados científicas Scopus e Web of Science em dezembro de 2020. As palavras-chave foram uma combinação de "agrícola" ou "floresta" com o operador booleano AND e o nome das enzimas: álcool desidrogenase/ADH, malato desidrogenase/MDH, alfa-amilase/AMS, peroxirredoxina/PERX e LEA. Oitenta e dois artigos abordando enzimas em espécies agrícolas ou florestais foram incluídos na análise. Os artigos foram publicados no período de 1976 a 2020, com média de publicação anual de 12,2. A taxa de crescimento percentual anual de 2,52\% e os artigos foram desenvolvidos por 337 autores. As culturas mais estudadas são Oryza sativa L., Glycine max L., Zea mays L., Hordeum vulgare L., espécimes dos gêneros Triticum e Brassica. As espécies florestais pertenceram aos gêneros Pinus, Picea, Nothofagus, Quercus e Sorbus, e a espécie Fagus sylvatica L. Os principais tecidos utilizados para extração são folhas, sementes, botões e raízes. Os estudos tratam principalmente de enzimas ou proteínas como marcadores associados a estresses abióticos e à estrutura ou diversidade genética.

Palavras-chave: ADH; Alfa-amilase; MDH; Proteínas LEA; Peroxirredoxinas. 


\begin{abstract}
Resumen
Las proteínas y las enzimas son marcadores bioquímicos informativos que se utilizan con frecuencia en estudios de plantas. El objetivo de este trabajo fue dar a conocer los estudios con enzimas y proteínas utilizadas como marcadores bioquímicos en cultivos y especies forestales. Los artículos fueron buscados en las bases de datos científicas Scopus y Web of Science en diciembre de 2020. Las palabras clave eran una combinación de "agrícola" o "forestal" con el operador booleano AND y el nombre de las enzimas: alcohol deshidrogenasa /ADH, malato deshidrogenasa / Proteínas MDH, alfa-amilasa, peroxiredoxina y LEA. En el análisis se incluyeron 82 artículos sobre enzimas en especies agrícolas o forestales. Los artículos fueron publicados desde 1976 hasta 2020, con una publicación anual promedio de 12.2. La tasa de crecimiento porcentual anual del 2,52\% y los artículos fueron desarrollados por 337 autores. Los cultivos más estudiados son Oryza sativa L., Glycine max L., Zea mays L., Hordeum vulgare L., ejemplares de los géneros Triticum y Brassica. Las especies forestales pertenecían a los géneros Pinus, Picea, Nothofagus, Quercus y Sorbus ya la especie Fagus sylvatica L. Los principales tejidos utilizados para la extracción son hojas, semillas, yemas y raíces. Los estudios tratan principalmente de enzimas o proteínas como marcadores asociados a los estreses abióticos y la estructura o diversidad genética.
\end{abstract}

Palabras clave: ADH; Alfa-amilasa; MDH; Proteínas LEA; Peroxiredoxinas.

\title{
1. Introduction
}

The first molecular technique used to identify and differentiate genetic properties was biochemical markers based on protein and enzyme. They result in zymograms in which the variation in band intensity is a function of enzymatic activity, the enzyme's quaternary structure, the number of loci, and the number of alleles at the locus (Alfenas et al., 1991; Ramalho et al., 2012).

An enzymatic reaction can be expressed in isoenzymes, allelic variants of the same enzyme, and encoded by different sites. Alternatively, allozymes represent a phenotypic expression of alleles at the same locus. Polymorphisms in isoenzyme are alleles variations and contribute to the elucidation of the genome (Alfenas et al., 1991; Kumar et al., 2018).

The discovery of isoenzymes provided researchers with simple markers and studied biological phenomena. These markers are direct products of the alleles. Therefore, it is possible to select the individual with the desired phenotype (Múdry et al., 2011; Ramalho et al., 2012). For many species, morphological descriptions alone are insufficient to differentiate differences in varieties. Therefore, combining field choices with biochemical markers it provides an efficient alternative for detecting existing genetic diversity.

Biochemical, genetic markers are less affected by environmental changes, which guarantees the specific stability of the biological ones and, consequently, a reliable result (Kumar et al., 2018). A protein or enzymatic analysis of species in the field or greenhouse is also advantageous, as most isoenzymes are present in the first stages of germination (Nikolić et al., 2008; Nikolić and Nikolić, 2010), ensuring savings in the study time.

The advantages of biochemical markers are codominant pattern, identifiable phenotypic, technically harnessed, and low cost, compared to other genetic markers (Souza, 2015; Yudina, 2012). Isoenzymes have been studied to distinguish varieties for selection and breeding (Li et al., 2015; Metwali, 2012); diversity of plant for population genetics (Daoura et al., 2018); phylogenetic studies (Colunga-Garciamarin et al., 1999); pathogens resistance (Sghaier-Hammami et al., 2013); stress tolerance (Lee et al., 2013; Sergeant et al., 2011) and genetic mapping in cultivars and their wild relatives (Sanghamitra et al., 2017).

From a methodological point of view, when working with these markers, some factors can result in the electrophoresis results: sample size and quality, protein concentration, retention level and type of medium, buffer $\mathrm{pH}$, and electrical currentvoltage applied (Zeidler, 2000). Another aspect of being considered is identifying the most discriminating enzyme systems in each species or group of species (Martins et al., 2007). Compiling information defined from studies with these markers in crops and forest species can contribute to making the adjustment of protocols more efficient and obtaining more accurate results. Therefore, the objective of the present work was to present the state of the art of studies with enzymes and proteins 
used as biochemical markers in crops and forest species.

\section{Methodology}

The articles had prospected in Scopus's scientific databases (http://www.scopus.com) and Web of Science (http://www.webofknowledge.com). The study was carried out in December 2020. The keywords were the combination of "agricultural" or "forest" with Boolean AND before the enzymes: alcohol dehydrogenase/ADH, malate dehydrogenase/MDH, alpha-amylase/AMS, peroxiredoxin/PERX, and LEA proteins. The keywords prospected in the title, abstract, and/or keywords of scientific articles; for the search, a time frame was not defined (Figure 1).

Figure 1 - Steps applied to the bibliometric study of enzymes in agricultural and forest species.

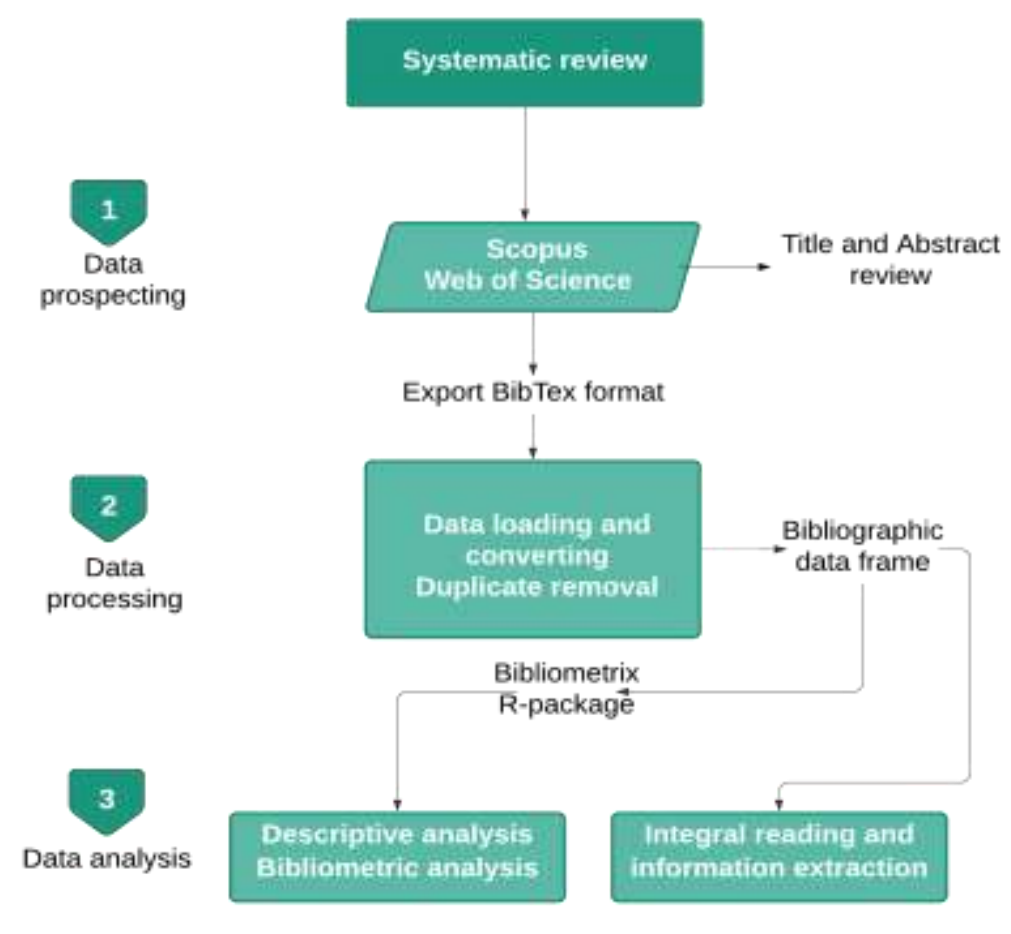

Source: Own authorship.

Documents were reviewed by title and abstract, and articles that did not match the keywords "agricultural" or "forest" associated with the enzymes described were excluded from the research. Metadata referring to scientific publications obtained for each term in the two databases were exported in BibTex format, combined as a single dataset, and duplicated files removed. Subsequently, descriptive and bibliometric analyzes were carried out with the aid of the Bibliometrix package of the $\mathrm{R}$ software (Aria \& Cuccurullo, 2017). All articles were evaluated to identify the plant tissue used in the studies, enzymes, and the research purpose.

\section{Results and Discussion}

The prospection returned 124 documents indexed in the Web of Science (50) and Scopus (74) databases. Forty-two articles duplicated were removed - the temporal framework of 1976 to 2020, with an annual publication average of 12.2. Three hundred thirty-seven authors developed the annual percentage growth rate of $2.52 \%$ of articles. A significant number of articles were published in 2010, 2011, and 2014 (5 documents) and 2018 (7 documents), whose primary origin is China (13 papers) and Brazil (12 articles). 
Bibliometry to know a conceptual structure of enzymes leads to a correspondence analysis performed and generated by the word clustering dendrogram (Figure 2). On the x-axis, they are the main words or less that will be grouped and, on the $y$ axis, the height that measures the distance between terms or groups of words, considering this distance as words will be grouped.

Figure 2 - Dendrogram of co-word analysis of articles on enzymes in agricultural and forest species.

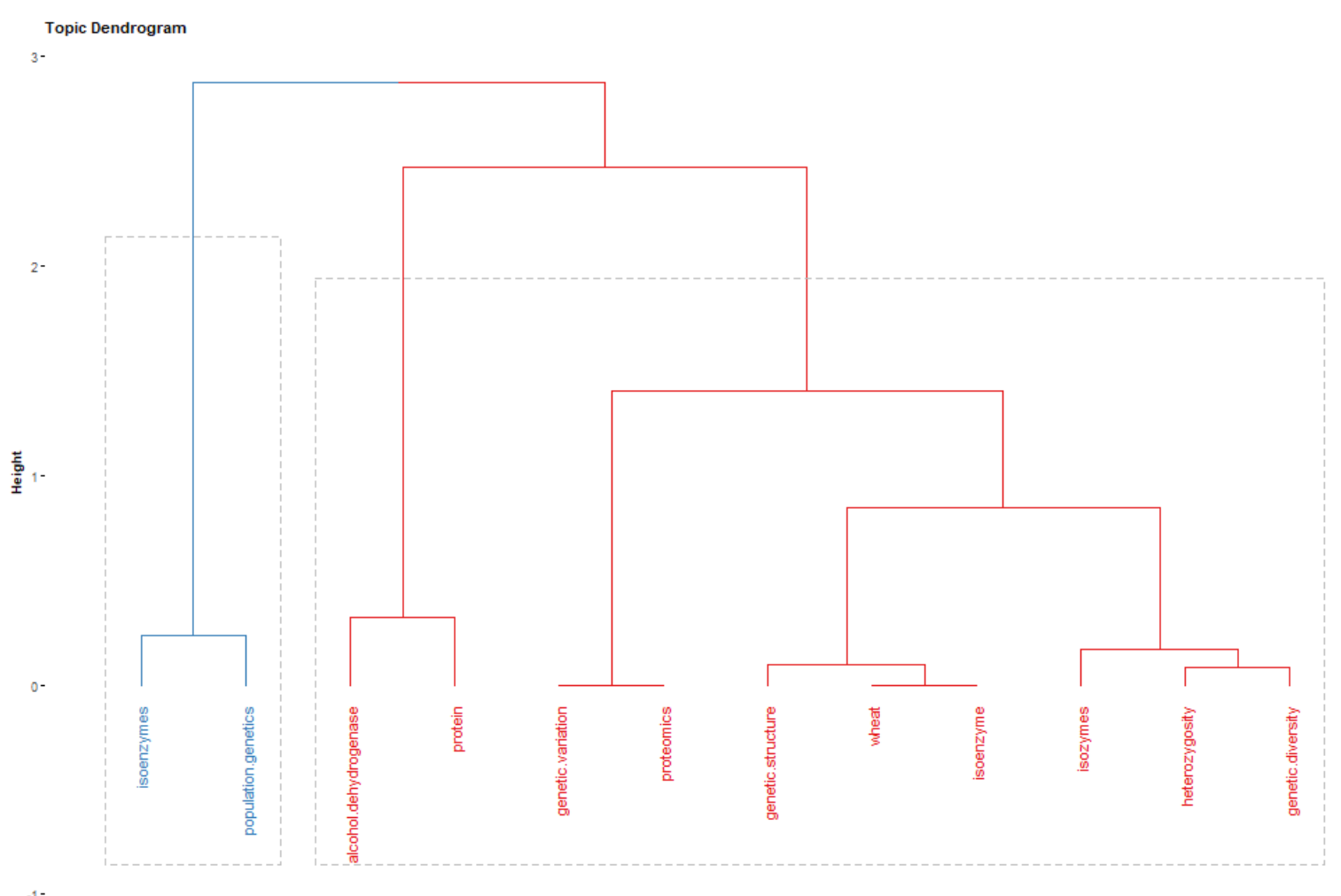

Source: own authorship.

For the set of documents, there is the formation of two groups. Group 1 is formed by the word's isoenzymes and derivative genetics. Group 2 is formed by subgroups, in which terms related to genetics are also present, such as genetic structure, genetic diversity, and genetic variation.

A full review of the documents revealed that the most studied agricultural species are Oryza sativa L., Glycine max L., Zea mays L., Hordeum vulgare L., and species of the genus Triticum and Brassica. The forest species were Pinus (Pinus halepensis Mill., Pinus cembra L., Pinus sylvestris L., Pinus tabulaeformis Carr., Pinus brutia Ten.), Picea (Picea abies Karst. and Picea obovata Ledeb.), Nothofagus (Nothofagus nervosa (Phil.) Dimitri \& Milano, Nothofagus antarctica (Forst) and Nothofagus dombeyi (Mirb.) Oerst.), Quercus (Quercus ilex L. and Quercus robur L.), Sorbus (Sorbus torminalis L. and Sorbus aucuparia L.) in addition to the species Fagus sylvatica $\mathrm{L}$. 
Table 1 - Species, tissue, and objectives of the studies carried out with the enzymes alcohol dehydrogenase (ADH), malate dehydrogenase (MDH), LEA proteins (LEA), alpha-amylase (AMS) and peroxirredoxine (PRDX).

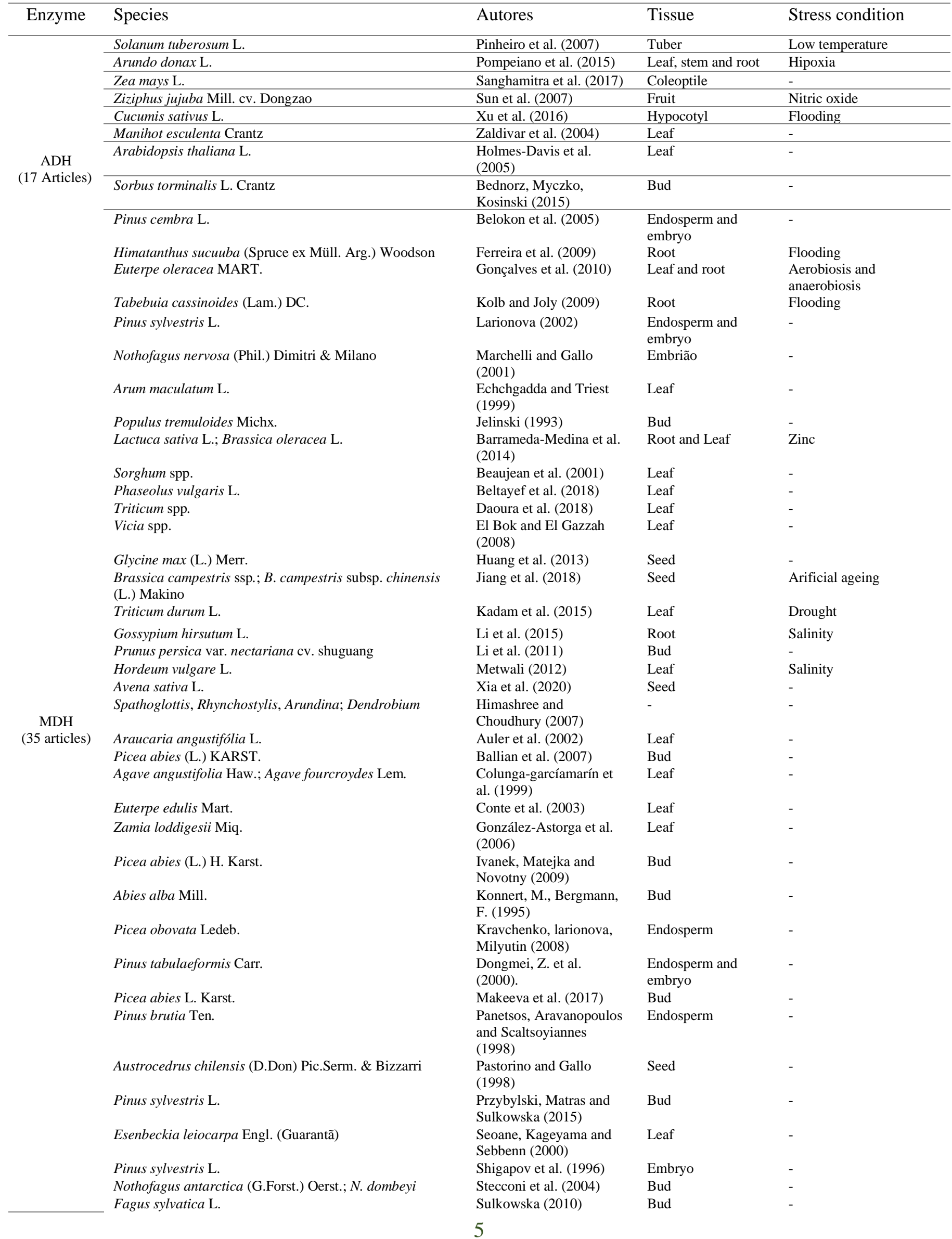




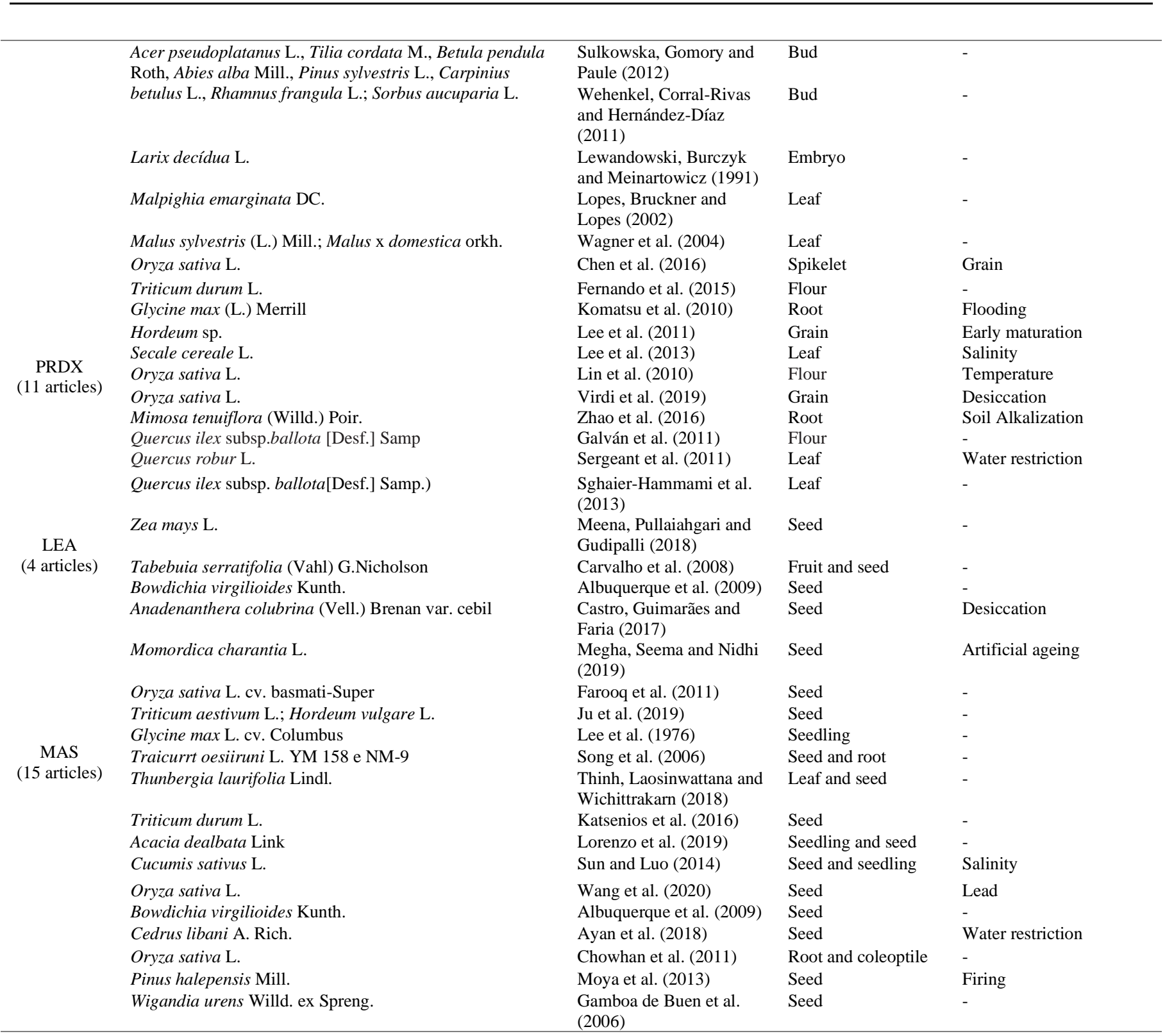

Source: Authors.

Enzymes are mainly extracted from leaf, seed, bud, and root (Table 1). The objectives of studies with enzymes in agricultural and forestry plants ranged from the enzymes or proteins under abiotic stresses and structure or genetic diversity of populations. Studies carried out with alcohol dehydrogenase enzyme (ADH EC 1.1.1.1) have as main objectives to evaluate the genetic diversity and structure of populations (Bednorz et al., 2015; Belokon et al., 2005; Echchgadda and Triest, 1999), identification of the purity of hybrids and their lines (Sanghamitra et al., 2017). ADH activity during germination and plant growth (Gonçalves et al., 2010) was evaluated using genotypes under temperature variation (Pinhero et al., 2007), prolonged deficiency of oxygen (Pompeiano et al., 2015), and flooding (Kolb and Joly, 2009).

For the enzyme malate dehydrogenase (MDH EC 1.1.1.37), there was the most significant number of articles (35) that focused mainly on genetic diversity and structure (Corral-Rivas and Hernández-Díaz, 2011; Daoura et al., 2018; Przybylski et al., 2015; Sulkowska et al., 2012). The artificial aging on seed respiration (Jiang et al., 2018) and changes in respiratory functions (Xia et al., 2020) were evaluated. Furthermore, identify plants tolerant to soil salinity (Li et al., 2015; Metwali, 2012), drought (Kadam et al., 2015), and excess of Zn (Barrameda-Medina et al., 2014).

Eleven studies were carried out with peroxiredoxins (Prxs EC 1.11.1.15) with protein expression during the grain 
filling (Chen et al., 2016), water deficit (Sergeant et al., 2011), high temperatures (Lin et al., 2010), salinity (K. Lee et al., 2013), sodium carbonate (Zhao et al., 2016) and responses to pathogens (Sghaier-Hammami et al., 2013). Heat-resistant proteins, of the LEA type (Late Embryogenesis Abundant), were differentially expressed in seeds after imbibition (Meena et al., 2018); in desiccation tolerance (Castro et al., 2017; Carvalho et al., 2008), and to elucidate biochemical events occurring during germination (Albuquerque et al., 2009).

Alpha-amylase enzymes (1,4- $\alpha$-D-glucan glucanohydrolase; EC 3.2.1.1) were studied in studies investigating seeds storage of different aging conditions (Bansal et al., 2019), in the imbibition process (Albuquerque et al., 2009), during germination (Lorenzo et al., 2020; Y. D. Sun and Luo, 2014) and water deficiency (Ayan et al., 2018) and exposure to fire (Moya et al., 2013). There were a small number of studies distributed over time. It may be related to the particularities of reagents, volumes, and laboratory techniques that each species requires in its enzyme extraction and protocol. The first studies with enzymes and proteins in plants date to the 70s (K. C. Lee et al., 1976), and new studies are being carried out nowadays (Bansal et al., 2019; Xia et al., 2020), a fact that reinforces the important role of enzymes and proteins for inferences in plant species.

Bibliometry permits evaluating words found among concepts that co-occur in titles, keywords, or abstracts; therefore, it uses the actual content of the documents to build a similarity measure (Zupic and Čater, 2015). The mapping and grouping the most important fields of articles, in such a way, it is possible to represent a knowledge base incorporated in the collection to identify documents and explore how different themes developed in a research domain (Aria and Cuccurullo, 2017; Li et al., 2015b). We present some specific aspects of the enzymes in focus in this study.

\section{Alcohol dehydrogenase}

The alcohol dehydrogenase enzyme is part of the class of enzymes called oxidoreductases. Its coenzyme is NAD +, and two Cys with sulfhydryl form the active site (Sun et al., 2007). This enzyme participates in ethanol oxidation to acetaldehyde and NADH to NAD + in alcoholic fermentation. It is remarkable that in stressful situations, the aerobic metabolism gives way to the anaerobic path, with a strong relation to the increase of the ADH activity in plants in this kind of stress. This fact is caused by the involvement of ADH in anaerobic respiration (Acquaah, 1992). Therefore, this enzyme is considered an anaerobic polypeptide and a marker of anaerobic activities in plants (Pompeiano et al., 2015). Nitric oxide can inhibit the enzymes $\mathrm{ADH}$ and $\mathrm{LDH}$, preventing anaerobic respiration and preventing the binding between the enzyme's sulfhydryl and ZnZ + (Sun et al., 2007).

There is a decrease in energy production in low oxygen conditions resulting from the shift from aerobic to anaerobic respiration, followed by alcoholic fermentation. It converts pyruvate into ethanol mediated by alcohol dehydrogenase and pyruvate decarboxylase (Pompeiano et al., 2015). In cases of flooding, the diffusion of oxygen between cells is 1000 times less than in a normal situation. For this reason, there is a change to the anaerobic metabolic route (Xu et al., 2016). It is known that high levels of ADH can signify ethanol toxicity in flood-affected plants (Jelinski, 1993). It is also stated that, in these cases, there is an increase in the production of lactate and ethanol, the final product of alcoholic fermentation, and that requires the action of PDC (pyruvate decarboxylase) and ADH (Kolb \& Joly 2009).

Increased alcohol dehydrogenase activity is an essential process in flood-tolerant conditions. In this situation, there is a high production of ethanol to maintain energy balance. Such accumulation can be harmful to plants, and there must be ways to eliminate the toxic product. Otherwise, there is death (Ferreira et al., 2009). Stress transmitted by low temperature generates an increase in ADH in maize and rice seedlings, in addition to evidence of change in expression in proteins that convert starch into sugar in tubers. In potatoes, lactate and ethanol production is accelerated due to the higher expression of ADH, LDH (lactate dehydrogenase), and PDC (Pinhero et al., 2007). Ethanol formation reduces the effects caused by the accumulation of 
lactate, which acidifies cell $\mathrm{pH}$, during anaerobic respiration (Gonçalves et al., 2010).

\section{Malate dehydrogenase}

Malate dehydrogenase belongs to the oxidoreductase class. The enzyme acts on the last pathway of the tricarboxylic acid (CAT) or Krebs cycle by oxidation of malate to oxaloacetate. This reaction has as cofactor NAD, protecting plants from oxidative stress (Kadam et al., 2015). The tricarboxylic acid cycle is the second stage of plant respiration, taking place in the mitochondrial matrix. It is essential in synthesizing reducing compounds such as FADH2 and NADH to complete the respiratory process and the formation of carbon skeletons, fundamentals for cellular metabolism (Kerbauy, 2008). Furthermore, it lacks the metabolism of lipids, proteins, nucleic acids, and secondary compounds, all combined with cells (Li et al., 2011).

$\mathrm{MDH}$ is very compatible with $\mathrm{Zn}$ and appears to be an essential compound in anion synthesis during the stress generated by zinc accumulation (Barrameda-Medina et al., 2014). As it is a respiratory enzyme, its expression increases during seed imbibition. Its degradation occurs with the increase in the level of toxic and oxidative substances (Jiang et al., 2018), typical of plants under some biotic or abiotic stress. In C4 plants, MDH converts oxaloacetic acid into malate, a vital carbon supplier for photosynthesis. Thus, it directly affects the composition and increases in productivity of such crops (Beaujean et al., 2001; Kerbauy, 2008).

\section{Alfa-amylase}

The alpha-amylase belongs to the family of endoamylases (glycosyl hydrolases) (Zorzin, 2014). The group is hydrolytic enzymes that catalyze starch into smaller chains, converting amylose and amylopectin into smaller molecules, such as maltose and glucose (Expasy, 2018). There are three types of amylases, the $\alpha$ - (E.C. 3.2.1.1) and $\beta$-amylases (E.C. 3.2.1.2), most frequently investigated in research (Jaaska, 1983). The third type is glucoamylase (E.C. 3.2.1.3). Different amylases are distinct based on their physical and compound properties: an $\alpha$-amylase is intolerant to $\mathrm{pH}<3.6$ and is activated by calcium (Frydenberg, 1965).

Amylases are one of the oldest and most important industrial enzymes. These comprise hydrolases, which hydrolyze starch molecules to refine various products such as dextrin and progressively smaller polymers composed of glucose units. Large matrices of amylases are involved in complete starch degradation. However, the alpha-amylases are most sought after hydrolyzing the 1,4-glycosidic bond within the molecule. A-amylase holds the largest market share in sales of enzymes with its application in the starch industry and its well-known use in the bakery. With the advent of new frontiers in biotechnology, the spectrum of application of alpha-amylase has also expanded to medicinal and analytical chemistry, automatic dishwashing, textile desizing, and the pulp and paper industry. Amylases are ubiquitous, produced by plants, animals, and microorganisms (Gupta et al., 2003).

Alpha-amylase is an approximately $50 \mathrm{kDa}$, calcium-dependent, monomeric protein composed of 512 amino acids and three anterior domains A, B, and C (Zorzin, 2014). The active site of alpha-amylase is in a long gap between domains A and $\mathrm{B}$. The cofactor $(\mathrm{Ca} 2+)$ binds to the enzyme in the gap between domains A and B and can stabilize a three-dimensional structure as an allosteric activator. Domain B is inserted between domains A and C and is linked to domain A by a disulfide bond. Domain $\mathrm{C}$ has a beta-sheet structure, appears independent, and is related to domain A by a single polypeptide chain (Whitcomb \& Lowe, 2013).

In addition, binding to calcium, the enzyme has a chlorine-binding site in domain A, close to the active site. The substrate-binding site contains five subsites, with the catalytic site positioned at subsite 3. An alpha-amylase cleaves preferentially as alpha-1,4 glycosidic bonds present within the molecule (Whitcomb \& Lowe, 2013; Zhang et al., 2013). 


\section{LEA proteins}

LEA proteins are classified as hydrophilic. These proteins have an affinity for water, thus keeping the seed hydrated for longer and preventing it from becoming denatured at high prices (Albuquerque et al., 2009; Castro et al., 2017). These are synthesized in seed development in the embryogenesis stage. The primary function of LEA proteins is to make plants desiccation-tolerant, preventing water loss and thus maintaining the physical properties of proteins in good working order. Therefore, these are found in orthodox seeds that are already necessary because they tolerate dehydration without physical and physical losses (Castro et al., 2017; Meena et al.,2018).

The hydrophilic amino acids in plants with LEA proteins are ordered in repeated sequences, divided by their biochemical properties and similar functions (Hong-Bo et al., 2005). Dehydrins, rich in lysins, are the most prominent and can be found in rice seeds (Oryza sativa L.) and corn (Zea mays L.).

\section{Peroxiredoxins}

Peroxiredoxin is a large family of peroxidases. They act in reducing peroxides, using cysteine residue, called Cys (Cp) peroxidative, functioning as a site of oxidation by peroxides (Hall et al., 2011; Rhee, 2016). The presence and location of these Cys define a classification of the family into subfamilies, namely, 2-Cys, atypical 2-Cys, and 1-Cys Prx (Chae et al., 1994; Rhee, 2016; Wood et al., 2003).

The enzymes are related to the thiol group of cysteine (known as peroxidase cysteine) from the $\mathrm{N}$-terminal of the enzyme to sulfenic acid in the reduction reaction of $\mathrm{H} 2 \mathrm{O} 2$ or other hydroperoxides present in water or alcohols. Essential amino acid residues, peroxidase cysteine, help create a low pKa space (acid constant) that facilitates the ionization of the thiol group to the thiolate anion. Among these residues, a threonine and an arginine stand out, which together with a peroxidase cysteine form a so-called catalytic triad (Komatsu et al., 2010; Zhao et al., 2016).

The constituted peroxiredoxins are characterized by Kim et al. (1988), with Saccharomyces cerevisiae being the first representative to be described. They are considered a superfamily, as they are present in both eukaryotic and prokaryotic organisms. According to work carried out by Hofmann (2002), all living organisms express these proteins in large quantities. They aid in response to high stress due to high levels of salinity. When identified molecularly, identify activated genes, and provide a complex network of physiological mechanisms at work intolerance of the saline environment (Lee et al., 2013).

In studies on their action on agricultural and forestry plants, some activities performed by these proteins were detected, including the presence in rice grains (Oryza sativa). Acting as flood-responsive proteins in soybean (Komatsu et al., 2010), in addition to being involved in the oxidative stress response in green oak (Quercus ilex subsp. ballota [Desf.] Samp.) (Galván et al., 2011). The protection against oxidation and germination in barley seeds (Hordeum vulgare) subjected to $\mathrm{H} 2 \mathrm{O} 2$ (Lee et al., 2011) and probable activity in resistance to saline stress (Lee et al., 2013) were also identified.

Agricultural species evaluated by MDH showed more variations. In alpha-amylase, there was little similarity between the experimental methods adopted. Physiological studies such as cell respiration, germination processes, chlorophyll, and toxicity were monitored by MDH. For LEA proteins, the methods differed from agricultural and forest species. However, most of the studies are of species under stress.

In studies related to peroxiredoxins, variation in extraction methods was noticeable, using the SDS-urea and phenol extraction method for agricultural species. The protocol more cited for the forest species were TCA-acetone and TCA-acetone phenol. 


\section{Final Considerations}

Studies with enzymes mainly use extracts using leaf, seed, bud, and root. To access this information using bibliometry could support defining the best protocols and tissues to establish the planning for studies and collecting. Even with diverse protocols, the biochemical markers are useful for genetic and physiological studies in seeds, buds, and leaves, i.e., many of the tissues used and identified in the articles evaluated.

A significant challenge for successful analysis is planning the studies involving biochemical markers, which requires a good literature review and, in most cases, protocol adjustments that take time to be standardized. In addition, it is crucial to choose the best tissue depending on the objectives and the species. Thus, it is worth investigating to initiate a study planning an excellent bibliographic search instead of spending time with mistakes and successes in adjusting protocols that demand time, costs, and technical experience.

\section{References}

Albuquerque, K. S., Guimarães, R. M., Almeida, I. F. D., \& Clemente, A. D. C. S. (2009). Alterações fisiológicas e bioquímicas durante a embebição de sementes de sucupira-preta (Bowdichia virgilioides Kunth.). Revista Brasileira de Sementes, 31, 249-258.

Acquaah, G. (1992). Practical protein electrophoresis for genetic research. Dioscorides Press.

Alfenas, A. C., Peters, I., Brune, W., \& Passador, G. C. (1991). Eletroforese de proteínas e isoenzimas de fungos e essências florestais. UFV.

Aria, M., \& Cuccurullo, C. (2017). bibliometrix: An R-tool for comprehensive science mapping analysis. Journal of Informetrics, 11(4), 959-975. https://doi.org/10.1016/j.joi.2017.08.007

Auler, N. M. F., Reis, M. S. D., Guerra, M. P., \& Nodari, R. O. (2002). The genetics and conservation of Araucaria angustifolia: I. Genetic structure and diversity of natural populations by means of non-adaptive variation in the state of Santa Catarina, Brazil. Genetics and molecular biology, $25,329-338$.

Ayan, S., Turfan, N., Nurten Yer, E., Šeho, M., Barş Özel, H., \& Ducci, F. (2018). Antioxidant variability of the seeds in core and marginal populations of taurus cedar (Cedrus libani A. Rich.). Šumarski list, 142(11-12), 600-600.

Ballian, D., Bogunić, F., \& Božič, G. (2007). Genetic Variability of Norway Spruce (Picea abies/L./H. Karst.) in the Bosnian Part of the Dinaric Mountain Range. Sumarski list, 131(5-6), 237-246.

Bansal, M., Bedi, S., \& Kaushal, N. (2019). Physiological, Biochemical and Molecular Changes in Relation to Different Storage Conditions and Accelerated Ageing in Bitter Gourd (Momordica charantia L.) cv. Punjab 14 Seeds. Indian Journal of Agricultural Biochemistry, 32(1), 101-105.

Barrameda-Medina, Y., Montesinos-Pereira, D., Romero, L., Ruiz, J. M., \& Blasco, B. (2014). Comparative study of the toxic effect of Zn in Lactuca sativa and Brassica oleracea plants: I. Growth, distribution, and accumulation of $\mathrm{Zn}$, and metabolism of carboxylates. Environmental and experimental botany, 107, 98-104.

Beaujean, A., Issakidis-Bourguet, E., Catterou, M., Dubois, F., Sangwan, R. S., \& Sangwan-Norreel, B. S. (2001). Integration and expression of Sorghum C4 phosphoenolpyruvate carboxylase and chloroplastic NADP+-malate dehydrogenase separately or together in C3 potato plants. Plant Science, 160(6), 11991210 .

Bednorz, L., Myczko, L., \& Kosinski, P. (2015). An assessment of genetic diversity following natural regeneration of Sorbus torminalis in the Forest District of Jamy (northern Poland). Dendrobiology, 73.

Belokon, M. M., Belokon, Y. S., Politov, D. V., \& Altukhov, Y. P. (2005). Allozyme polymorphism of Swiss stone pine Pinus cembra L. in mountain populations of the Alps and the Eastern Carpathians. Russian Journal of Genetics, 41(11), 1268-1280.

Beltayef, H., Melki, M., Saidi, W., Samaali, S., Muscolo, A., Cruz, C., \& Garoui, T. (2018). Betterment of biological nitrogen fixation in snap bean under mediterranean semi-arid conditions. Bulgarian Journal of Agricultural Science, 24(2), 244-251.

Castro, L. E., Guimarães, C. C., \& Faria, J. M. R. (2017). Physiological, cellular and molecular aspects of the desiccation tolerance in Anadenanthera colubrina seeds during germination. Brazilian Journal of Biology, 77, 774-780.

Chae, H. Z., Robison, K., Poole, L. B., Church, G., Storz, G., \& Rhee, S. G. (1994). Cloning and sequencing of thiol-specific antioxidant from mammalian brain: alkyl hydroperoxide reductase and thiol-specific antioxidant define a large family of antioxidant enzymes. Proceedings of the National Academy of Sciences, 91(15), 7017-7021.

Chauhan, H., Khurana, N., Agarwal, P., \& Khurana, P. (2011). Heat shock factors in rice (Oryza sativa L.): genome-wide expression analysis during reproductive development and abiotic stress. Molecular Genetics and Genomics, 286(2), 171-187.

Chen, T., Xu, G., Wang, Z., Zhang, H., Yang, J., \& Zhang, J. (2016). Expression of proteins in superior and inferior spikelets of rice during grain filling under different irrigation regimes. Proteomics, 16(1), 102-121. 
Colunga-Garci' aMari’ n, P., Coello-Coello, J. N., Eguiarte, L. E., \& Pin ero, D. (1999). Isozymatic variation and phylogenetic relationships between heneque' n (Agave fourcroydes) and its wild ancestor A. angustifolia (Agavaceae). American Journal of Botany, 86(1), 115-123.

Conte, R., Nodari, R. O., Vencovsky, R., \& Dos Reis, M. S. (2003). Genetic diversity and recruitment of the tropical palm, Euterpe edulis Mart., in a natural population from the Brazilian Atlantic Forest. Heredity, 91(4), 401-406.

Daoura, B. G., Saeed, I., Song, Q., Yang, Y., Chen, L., \& Hu, Y. G. (2018). Activities of C4 Photosynthetic Pathway Enzymes in Different Bread Wheat Genotypes under Field Conditions. Sains Malaysiana, 47(2), 235-242.

Dongmei, Z., Yue, L., Xihuan, S., Chunxiao, Z., Guofeng, L., \& Jun, L. (2000). A primary study on the mating system of three different populations within one improvement procedure of Pinus tabulaeformis Carr. Journal of Beijing Forestry University, 22(5), 13-18.

Echchgadda, G., \& Triest, L. (1999). Genetic diversity in Arum maculatum from two urban forests. Belgian Journal of Botany, 95-103.

El Bok, S., \& El Gazzah, M. (2008). Isozymes variation of some species of the genus Vicia (Fabaceae) collected from Tunisia. International Journal of Integrative Biology, 4(2), 81.

Farooq, M., Atique-ur-Rehman, Aziz, T., \& Habib, M. (2011). Boron nutripriming improves the germination and early seedling growth of rice (Oryza sativa L.). Journal of plant nutrition, 34(10), 1507-1515.

Ferreira, C. S., Piedade, M. T. F., Franco, A. C., Gonçalves, J. F. C., \& Junk, W. J. (2009). Adaptive strategies to tolerate prolonged flooding in seedlings of floodplain and upland populations of Himatanthus sucuuba, a Central Amazon tree. Aquatic Botany, 90(3), $246-252$.

Frydenberg, O., \& Nielsen, G. (1965). Amylase isozymes in germinating barley seeds. Hereditas, 54(2), 123-139.

Galván, J. V., Valledor, L., Cerrillo, R. M. N., Pelegrín, E. G., \& Jorrín-Novo, J. V. (2011). Studies of variability in Holm oak (Quercus ilex subsp. ballota [Desf.] Samp.) through acorn protein profile analysis. Journal of proteomics, 74(8), 1244-1255.

Gamboa-deBuen, A., Cruz-Ortega, R., Martínez-Barajas, E., Sánchez-Coronado, M. E., \& Orozco-Segovia, A. (2006). Natural priming as an important metabolic event in the life history of Wigandia urens (Hydrophyllaceae) seeds. Physiologia Plantarum, 128(3), 520-530.

Gonçalves, J. F. D. C., Lima, R. B. S., Fernandes, A. V., Borges, E. E. D. L., \& Buckeridge, M. S. (2010). Physiological and biochemical characterization of the assai palm (Euterpe oleracea Mart.) during seed germination and seedling growth under aerobic and anaerobic conditions. Revista Árvore, $34,1045-4053$.

Gupta, R., Gigras, P., Mohapatra, H., Goswami, V. K., \& Chauhan, B. (2003). Microbial $\alpha$-amylases: a biotechnological perspective. Process biochemistry, 38(11), 1599-1616.

Hall, A., Nelson, K., Poole, L. B., \& Karplus, P. A. (2011). Structure-based insights into the catalytic power and conformational dexterity of peroxiredoxins. Antioxidants \& redox signaling, 15(3), 795-815.

Hofmann, B., Hecht, H., \& Flohé, L. (2002). Peroxiredoxins. Biological Chemistry, 383(3-4), 347-364

Holmes-Davis, R., Tanaka, C. K., Vensel, W. H., Hurkman, W. J., \& McCormick, S. (2005). Proteome mapping of mature pollen of Arabidopsis thaliana. Proteomics, 5(18), 4864-4884.

Huang, C. C., Wei, I. H., Huang, C. L., Chen, K. T., Tsai, M. H., Tsai, P., ... \& Tsai, G. E. (2013). Inhibition of glycine transporter-I as a novel mechanism for the treatment of depression. Biological psychiatry, 74(10), 734-741.

Ivanek, O., Matějka, K., \& Novotný, P. (2009). Genetic structure of two parts of Norway spruce stand near the alpine forest limit in the Krkonoše National Park. Zprávy Lesnického Výzkumu, 54(4), 300-306.

Jelinski, D. E. (1993). Associations between environmental heterogeneity, heterozygosity, and growth rates of Populus tremuloides in a cordilleran landscape. Arctic and Alpine Research, 25(3), 183-188.

Jiang, F. L., Bo, L. P., Xu, J. J., \& Wu, Z. (2018). Changes in respiration and structure of non-heading Chinese cabbage seeds during gradual artificial aging. Scientia Horticulturae, 238, 14-22.

Ju, C., Zhang, H., Yao, S., Dong, S., Cao, D., Wang, F., ... \& Yu, Y. (2019). Uptake, translocation, and subcellular distribution of azoxystrobin in wheat plant (Triticum aestivum L.). Journal of agricultural and food chemistry, 67(24), 6691-6699.

Kadam, S. D., Shukla, Y. M., Gupta, P., \& Zala, H. (2015). Studies on the Genetic Diversity of Wheat Genotypes (Triticum durum L.) in Response to Drought Stress Through Isozyme Markers. Indian Journal of Agricultural Biochemistry, 28(1), 39-47.

Katsenios, N., Bilalis, D., Efthimiadou, A., Aivalakis, G., Nikolopoulou, A. E., Karkanis, A., \& Travlos, I. (2016). Role of pulsed electromagnetic field on enzyme activity, germination, plant growth and yield of durum wheat. Biocatalysis and agricultural biotechnology, $6,152-158$.

Kerbauy, G. B. (2008). Fisiologia Vegetal (2nd ed.). Guanabara Koogan.

Kim, K. A. N. G. H. W. A., Kim, I. H., Lee, K. Y., Rhee, S. G., \& Stadtman, E. R. (1988). The isolation and purification of a specific “protector" protein which inhibits enzyme inactivation by a thiol/Fe (III)/O2 mixed-function oxidation system. Journal of Biological Chemistry, 263(10), 4704-4711.

Kolb, R. M., \& Joly, C. A. (2009). Flooding tolerance of Tabebuia cassinoides: metabolic, morphological and growth responses. Flora-Morphology, Distribution, Functional Ecology of Plants, 204(7), 528-535.

Komatsu, S., Sugimoto, T., Hoshino, T., Nanjo, Y., \& Furukawa, K. (2010). Identification of flooding stress responsible cascades in root and hypocotyl of soybean using proteome analysis. Amino Acids, 38(3), 729-738. 
Konnert, M., \& Bergmann, F. (1995). The geographical distribution of genetic variation of silver fir (Abies alba, Pinaceae) in relation to its migration history. Plant systematics and Evolution, 196(1), 19-30.

Kravchenko, A. N., Larionova, A. Y., \& Milyutin, L. I. (2008). Genetic polymorphism of siberian spruce (Picea obovata ledeb.) in middle Siberia. Russian Journal of Genetics, 44(1), 35-43.

Kumar, M., Chaudhary, V., Sirohi, U., Singh, M. K., Malik, S., \& Naresh, R. K. (2018). Biochemical and molecular markers for characterization of chrysanthemum germplasm: A review. Journal of Pharmacognosy and Phytochemistry, 7(5), 2641-2652.

Larionova, A. Y. (2002). Genetic variability in Scotch pine in the Southeastern part of its range. Russian Journal of Genetics, 38(12), 1391-1396.

Lee, K. C., Cunningham, B. A., Chung, K. H., Paulsen, G. M., \& Liang, G. H. (1976). Lead effects on several enzymes and nitrogenous compounds in soybean leaf (Vol. 5, No. 4, pp. 357-359). American Society of Agronomy, Crop Science Society of America, and Soil Science Society of America.

Lee, K. W., Choi, G. J., Kim, K. Y., Ji, H. C., Park, H. S., \& Lee, S. H. (2013). A proteomic approach to identify salt-responsive proteins in rye. Pak J Bot, 45, 1489-1496.

Lee, S. E., Park, S. J., Jung, J. A., Koh, T. S., Shim, M. Y., \& Kim, T. W. (2011). Proteomic Analysis of Seeds of Early Maturing Line of Barley,'Eam9'. Australian Journal of Crop Science, 5(7), 801-808.

Lewandowski, A., Burczyk, J., \& Meinartowicz, L. (1991). Genetic Structure and the Mating System in an Old Stand. Silvae Genetica, 4, 2.

Li, D. M., Ling, L. I., Yue, T. A. N., Chen, X. D., Zhang, H. S., Gao, D. S., \& Jin, L. I. (2011). Effect of photoperiod on key enzyme activities of respiration in nectarine buds during dormancy induction. Agricultural sciences in China, 10(7), 1026-1031.

Li, W., Zhao, F. A., Fang, W., Xie, D., Hou, J., Yang, X., ... \& Lv, S. (2015). Identification of early salt stress responsive proteins in seedling roots of upland cotton (Gossypium hirsutum L.) employing iTRAQ-based proteomic technique. Frontiers in plant science, 6, 732.

Li, W., Zhao, F. A., Fang, W., Xie, D., Hou, J., Yang, X., ... \& Lv, S. (2015). Identification of early salt stress responsive proteins in seedling roots of upland cotton (Gossypium hirsutum L.) employing iTRAQ-based proteomic technique. Frontiers in plant science, 6, 732.

Lin, C. J., Li, C. Y., Lin, S. K., Yang, F. H., Huang, J. J., Liu, Y. H., \& Lur, H. S. (2010). Influence of high temperature during grain filling on the accumulation of storage proteins and grain quality in rice (Oryza sativa L.). Journal of Agricultural and Food Chemistry, 58(19), 10545-10552.

Lopes, R., Bruckner, C. H., \& Lopes, M. T. G. (2002). Estimation of outcrossing rates in acerola (Malpighia emarginata) based on isoenzymic data. Pesquisa Agropecuária Brasileira, 37(3), 321-327.

Lorenzo, P., Reboredo-Durán, J., Muñoz, L., Freitas, H., \& González, L. (2020). Herbicidal properties of the commercial formulation of methyl cinnamate, a natural compound in the invasive silver wattle (Acacia dealbata). Weed Science, 68(1), 69-78.

Makeeva, V. M., Smurov, A. V., Politov, D. V., Belokon, M. M., Belokon, Y. S., Suslova, E. G., \& Rusanov, A. V. (2017). Gene pool state and degree of infestation by bark beetle (Ips tipographus L.) of Norway spruce (Picea abies L. Karst.) natural populations and planted stands in Moscow region. Russian journal of Genetics, 53(4), 445-454.

Marchelli, P., \& Gallo, L. A. (2001). Genetic diversity and differentiation in a southern beech subjected to introgressive hybridization. Heredity, 87(3), 284293.

Martins, C. C., Bovi, M. L. A., Mori, E. S., \& Nakagawa, J. (2007). Isoenzymes in the differentiation of three Euterpe species. Revista Árvore, $31(1)$, 51-57.

Meena, R. K., Pullaiahgari, D., \& Gudipalli, P. (2018). Proteomic analysis of heterotic seed germination in maize using F1 hybrid DHM 117 and its parental inbreds. Turkish Journal of Biology, 42(4), 352-370.

Metwali, E. M. (2012). Molecular studies on some barley genotypes in relation to salt stress tolerance. Life Science Journal, 9(1).

Carvalho, M. L. M. D., Nery, M. C., Oliveira, L. M. D., Hilhorst, H. W., \& Guimarães, R. M. (2008). Morphophysiological development of Tabeluia serratifolia Vahl Nich. seeds. Scientia Agricola, 65, 643-651.

Moya, D., De las Heras, J., Salvatore, R., Valero, E., \& Leone, V. (2013). Fire intensity and serotiny: response of germination and enzymatic activity in seeds of Pinus halepensis Mill. from southern Italy. Annals of forest science, 70(1), 49-59.

Múdry, P., Hricová, A., Libiaková, G., \& Gajdosová, A. (2011). Methodological Approaches to Simple Enzyme Polymorphism Analyses of Amaranth Species (Amaranthus sp.). Agriculture, 57(1), 1.

Nikolić, Z., Vujaković, M., \& Jevtić, A. (2008). Genetic purity of sunflower hybrids determined on the basis of isozymes and seed storage proteins/Pureza genética de híbridos de girasol determinada sobre la base de isoenzimas y proteínas de reserva en semilla/Pureté génétique d'hybrides de tournesol déterminée sur la base des isozymes et des protéines de réserve dans la graine. Helia, 31(48), 47-54.

Nikolić, Z. (2010). Application of genetic markers in seed testing and plant breeding. Ratarstvo i povrtarstvo, 47(2), 409-416.

Pinhero, R. G., Copp, L. J., Amaya, C. L., Marangoni, A. G., \& Yada, R. Y. (2007). Roles of alcohol dehydrogenase, lactate dehydrogenase and pyruvate decarboxylase in low-temperature sweetening in tolerant and susceptible varieties of potato (Solanum tuberosum). Physiologia plantarum, 130(2), 230-239.

Panetsos, K. P., Aravanopoulos, F. A., \& Scaltsoyiannes, A. (1998). Genetic variation of Pinus brutia from islands of the northeastern Aegean sea. Silvae Genetica, 47(2), 115-119. 
Pastorino, M. J., \& Gallo, L. A. (1998). Inheritance of isozyme variants in Austrocedrus chilensis (D. Don) Florin et Boutelje. Silvae Genetica, 47(1), 15-19.

Pompeiano, A., Vita, F., Alpi, A., \& Guglielminetti, L. (2015). Arundo donax L. response to low oxygen stress. Environmental and Experimental Botany, 111, $147-154$.

Przybylski, P., Matras, J., \& Sułkowska, M. (2015). Genetic variability of Scots pine (Pinus sylvestris L.) in maternal regions of provenance.

Ramalho, M. A. P., Santos, J. B., Pinto, C. A. B., Souza, E. A., Gonçalves, F. M. A., \& Souza, J. C. (2012). Genética na Agropecuária (5a). UFLA.

Rhee, S. G. (2016). Overview on peroxiredoxin. Molecules and cells, 39(1), 1.

Sanghamitra, P., Tiwari, A., Bose, L. K., \& Jambhulkar, N. N. (2017). Evaluating genetic purity of quality protein maize (QPM) inbreds and hybrids by biochemical and SSR markers. JAPS: Journal of Animal \& Plant Sciences, 27(5).

Sergeant, K., Spieß, N., Renaut, J., Wilhelm, E., \& Hausman, J. F. (2011). One dry summer: a leaf proteome study on the response of oak to drought exposure. Journal of proteomics, 74(8), 1385-1395.

Seoane, C. E. S., Kageyama, P. Y., \& Sebbenn, A. M. (2000). Forest fragmentation effects in population genetic structure of Esenbeckia leiocarpa Engl.(Guarantã). Scientia Forestalis, (57), 123-139.

Shigapov, Z. K., Timer'yanov, A. S., Yanbaev, Y. A., \& Shigapova, A. I. (1996). Dynamics of Genetic Structure in Generations on a Forest Seed Plantation and in a Natural Population of Scotch Pine Pinus sylvestris L. Russian Journal of Genetics, 32(10), 1183-1189.

Sghaier-Hammami, B., Valero-Galvàn, J., Romero-Rodríguez, M. C., Navarro-Cerrillo, R. M., Abdelly, C., \& Jorrín-Novo, J. (2013). Physiological and proteomics analyses of Holm oak (Quercus ilex subsp. ballota [Desf.] Samp.) responses to Phytophthora cinnamomi. Plant physiology and biochemistry, 71, 191-202.

Song, N. H., Yang, Z. M., Zhou, L. X., Wu, X., \& Yang, H. (2006). Effect of dissolved organic matter on the toxicity of chlorotoluron to Triticum aestivum. Journal of Environmental sciences, 18(1), 101-108.

Souza, D. C. L. (2015). Técnicas moleculares para caracterização e conservação de plantas medicinais e aromáticas: uma revisão. Revista Brasileira de Plantas Medicinais, 17, 495-503.

Stecconi, M., Marchelli, P., Puntieri, J., Picca, P., \& Gallo, L. (2004). Natural hybridization between a deciduous (Nothofagus antarctica, Nothofagaceae) and an evergreen (N. dombeyi) forest tree species: evidence from morphological and isoenzymatic traits. Annals of Botany, 94(6), 775-786.

Sułkowska, M. (2010). Genetic and ecotypic characterization of European beech (Fagus sylvatica L.) in Poland. Acta Silvatica et Lignaria Hungarica: An International Journal In Forest, Wood And Environmental Sciences, 6, 115-121.

Sułkowska, M., Gömöry, D., \& Paule, L. (2012). Genetic diversity of European beech in Poland estimated on the basis of isoenzyme analyses.

Sun, L. N., Liu, M. C., Zhu, S. H., Jie, Z. H. O. U., \& Wang, M. L. (2007). Effect of nitric oxide on alcoholic fermentation and qualities of Chinese winter jujube during storage. Agricultural Sciences in China, 6(7), 849-856.

Sun, Y. D., \& Luo, W. R. (2014). Effects of exogenous hydrogen sulphide on seed germination and seedling growth of cucumber (Cucumis sativus) under sodium bicarbonate stress. Seed Science and Technology, 42(2), 126-131.

Thinh, N. H., Laosinwattana, C., \& Wichittrakarn, P. (2018). Optimal extraction solvents use for extraction of Thunbergia laurifolia Linn. leaves and its mode of action on weed control. International Journal of Agricultural Technology, 14(7 Special Issue), 2067-2076.

Virdi, A. S., Singh, N., Pal, P., Kaur, P., \& Kaur, A. (2019). Evaluation of head and broken rice of long grain Indica rice cultivars: Evidence for the role of starch and protein composition to head rice recovery. Food Research International, 126, 108675.

Wagner, I., Maurer, W. D., Lemmen, P., Schmitt, H. P., Wagner, M., Binder, M., \& Patzak, P. (2014). Hybridization and genetic diversity in wild apple (Malus sylvestris (L.) Mill.) from various regions in Germany and from Luxembourg. Silvae Genetica, 63(1-6), 81-93.

Wehenkel, C., Corral-Rivas, J. J., \& Hernandez-Diaz, J. C. (2011). Genetic diversity in relation to secondary succession of forest tree communities. Polish Journal of Ecology, 59(1), 45-54.

Whitcomb D. C., \& Lowe M. E. (2013). Pancreatic Digestive Enzymes. Digestive Diseases and Sciences., 52, 1-17.

Wood, Z. A., Schröder, E., Harris, J. R., \& Poole, L. B. (2003). Structure, mechanism and regulation of peroxiredoxins. Trends in biochemical sciences, 28(1), $32-40$.

Xia, F., Cheng, H., Chen, L., Zhu, H., Mao, P., \& Wang, M. (2020). Influence of exogenous ascorbic acid and glutathione priming on mitochondrial structural and functional systems to alleviate aging damage in oat seeds. BMC plant biology, 20(1), 1-11.

Xu, X., Ji, J., Ma, X., Xu, Q., Qi, X., \& Chen, X. (2016). Comparative proteomic analysis provides insight into the key proteins involved in cucumber (Cucumis sativus L.) adventitious root emergence under waterlogging stress. Frontiers in plant science, 7, 1515.

Yudina, R. S. (2012). Malate dehydrogenase in plants: Its genetics, structure, localization and use as a marker.

Zaldivar, M. E., Rocha, O. J., Aguilar, G., Castro, L., Castro, E., \& Barrantes, R. (2004). Genetic variation of cassava (Manihot esculenta Crantz) cultivated by Chibchan Amerindians of Costa Rica. Economic Botany, 58(2), 204-213.

Zeidler, M. (2000). Electrophoretic analysis of plant isozymes. Biologica, 38, 7-16. 
Research, Society and Development, v. 10, n. 17, e05101724172, 2021

(CC BY 4.0) | ISSN 2525-3409 | DOI: http://dx.doi.org/10.33448/rsd-v10i17.24172

Zhang, J., Cui, J. H., Yin, T., Sun, L., \& Li, G. (2013). Activated effect of lignin on $\alpha$-amylase. Food chemistry, 141(3), 2229-2237.

Zhao, Q., Suo, J., Chen, S., Jin, Y., Ma, X., Yin, Z., ... \& Dai, S. (2016). Na 2 CO 3-responsive mechanisms in halophyte Puccinellia tenuiflora roots revealed by physiological and proteomic analyses. Scientific reports, 6(1), 1-23.

Zorzin, F. M. (2014). Avaliação da atividade de inibição de alfa-amilase e padronização do extrato aquoso da folha de Eugenia dysenterica.

Zupic, I., \& Čater, T. (2015). Bibliometric methods in management and organization. Organizational research methods, 18(3), 429-472. 